\title{
Alternative Globalization in Southern FRANCE: MINORITY LANGUAGE AS A Creative Tool in Occitan Popular Music
}

\section{Michael Spanu}

Paris has often been considered the cultural centre of France, especially as it is the home of many major recording companies. But during the 1970s, a significant number of folk music scenes appeared in other parts of France. The major attribute of these local scenes (in Brittany or Southern France for instance) was the lyrical emphasis on their regional cultural heritage and the use of traditional instruments or/and a regional language (Tenaille 2008; Hennion 2011). In Occitania, folk musicians' work was highly influenced by the rediscovery of Occitan melodies, tales and traditional instruments such as the cabrette or the hurdy-gurdy. The use of the Occitan language was also a significant characteristic of their music. Occitan is a Romance language that has existed for more than a thousand years. It was the troubadours' language from which chivalric romance emerged (Nelli 1989). For instance, the word »love in French (amour) comes from Occitan.

Despite the fame of Occitan music in the 1970s, singing in this language was not »natural «: not all the folk musicians and not all of their audience could understand it (some had already lost the link with their parents' or grandparents' language). Moreover, it revived a conflict with traditional French values based on the notion of »integration « or "assimilation « that implicitly requires the use of only one language (French) in the public sphere (Giordan 2002). But these Occitan musicians found alternative ways to produce and distribute their music by creating a specific and activist network of labels (Ventadorn and Revolum especially) and associations (Cestor 2005). It was therefore a structural way to fight against cultural centralism that was perceived as oppressive and elitist.

Now that a new generation of musicians claiming an Occitan identity has begun incorporating stylistic elements from rap, rock or metal, questions of language and identity have to be addressed again. In this article I will show 
how this new generation of Occitan artists challenges the idea of a pure and unique Occitan identity. Even though the high Occitan folk music ${ }^{1}$ scene appears to be reclusive towards this new Occitan popular music, there are still many connections between the two. However, creating and composing in Occitan continues to be a challenge for the new generation of popular musicians, whether they find inspiration in the folk repertoire or not. Nowadays, new popular musicians hardly eke out a living; they are stuck between the purist Occitan folk scene receiving public or regional subsidies and the popular music market that has very little interest in regional/local expressions. I will try to demonstrate how this specific local context has created a hierarchy of authenticity that plays an important role in popular musicians' practices. More specifically, this hierarchy often relies on a series of discourses claiming to preserve the Occitan identity, which has forced popular artists to find strategies to resist this »identity confinement «. This article is based on eighteen interviews I conducted with artists and bookers between October 2013 and May 2014.

\section{Power and Nostalgia in the Definition of Authentic Occitan Music}

In the late 1960s, many French singers from the south of France, who were inspired by Anglo-American folksingers (like e.g. Bob Dylan, Pete Seeger, Donovan, Woody Guthrie), such as Claude Marti or Los de Nadau, started to write songs in Occitan. The symbolic impact was strong among the Occitan community, especially considering the countercultural global context (Charles-Dominique/Defrance 2008: 16). Indeed, singing in Occitan was linked to a more general left-wing movement opposed to globalized culture that took the rambling man and his acoustic guitar as an example to follow (Charles-Dominique 2011: 138-139). At that time, the language was the main element of regional identity, since the instrumentation was minimal (acoustic guitar) and came from industrial manufactures, not local handcrafters. There weren't many Occitan bands that were specifically concerned with regionality as opposed to universality, such as Perlinpinpin Folc or Los del Sauveterre for instance. After the victory of the socialist party in 1981 these singers either became professional artists or lost their audience (Cestor 2005: 55) because the political battle for their cultural recognition

1 The difference I make between folk and popular music is mainly based on the notion of composition. Folk music focuses on a fixed repertoire of collected texts and melodies that are supposed to be authentically Occitan. 
had been supposedly won. The political dimension of these early folk singers made room for a vast cultural collecting initiative (sound material, dances, stories in the villages, etc.) named »revival« (even in French). What I call »historical deepness «, meaning a high level of collective memory and remembrance (Candau 1998), then became the major criteria to define the Occitan identity. Indeed, new Occitan music had to comply with what it was supposed to have been in the past, even if nobody could exactly tell how it sounded because of the lacking material. The collecting process was then highly ideological and political (Hennion 2011). It became an interpretation that reflected what the main activists wanted the Occitan culture to be in the present: nice-sounding homogenized music for dancing, with simple melodies and lyrics that evoked an idealized past. Until the early 1990 s very few Occitan bands had not played folk music from the traditional repertoire (Chabaud 2013).

Nevertheless, the militancy and tenacity of many Occitan partisans allowed for the creation of a folk music department at the French conservatory, an Occitan language bachelor at several universities (Pau, Toulouse, etc.) and, above all, bilingual schools (calandreta). This corresponds to a specific moment of French cultural history during the 1980s (Donnat 2003): on the one hand, there was a high-culture type of appropriation of genres that used to be popular (such as jazz and rock for instance, but in this case, regional folk music), and on the other hand, a hybridization of institutions that were traditionally elitist (conservatories, universities and schools embracing specific cultures, Occitan in this case).

The only remaining band of this early era of Occitan revival music is Nadau (1973-present), which is also one of the most successful and famous bands currently singing in Occitan. Their work on collective memory, their teaching skills during concerts and their anthem-like songs permitted them to build a very strong and large fan base (thousands of people go to their concerts). They could even afford to free themselves from the usual distribution network and specific media coverage, becoming economically and artistically independent:

»We don't have any booker, I never ask to play somewhere, I never promote the band really. People just phone me. I'm lucky for that. It puts me in a strong position, I only sing where I want. We have our own truck, 4 technicians... we can reach 4000 people with that. We don't depend on any booking company. We have our own recording studio, our own label« (Michel Maffrand 2014). ${ }^{2}$

2 All interview quotations were translated from French into English by the author. 
This is quite an exceptional situation for a band. No other Occitan band can claim to be in such a solid position. However, their success does not really go beyond the Occitan community. Even if their shows in Paris are always sold out, this is due to the strong Occitan community living in the capital and also due to the fans from the south of France who travel to the capital to support »their « band. The recognition of Nadau as a true ambassador of Occitan culture has to do with the way they managed to create a »soundscape « inspired by the Pyrenees Mountains, working as »both ideological space and physical place «, as Donna Weston (2012: 158) writes. In her article, Weston includes language in Nadau's soundscape, but without analysing the band's relationship with languages in general. Indeed, even these pioneers had to learn the Occitan language anew when they started singing. They had »forgotten « it because they could not use it outside their village when they were young or because their parents did not want them to speak it at all, believing that it would be a handicap for their future:

»People around me, people who loved me, they all spoke Occitan, so I didn't understand why we couldn't talk about them and their culture at school [...]. At 25, I was a mathematics teacher and I discovered this Occitan singer called Marti, singing in dialect, just like my grandmother. [...] On stage, he was asking > Why don't they talk about the language of my country at school?< [...] So I realized that a huge part of my history had been hidden from me [...] and I've spent my whole life like a salmon, swimming against the tide« (Michel Maffrand 2014).

So, as with many popular Occitan bands that have started since then, the learning process of the language went with the music practice. More generally, most of their Occitan identity had to be rebuilt. Thus, it has been a constant personal identity exploration for these artists, whether they use the repertoire of traditional Occitan lyrics or not. Nadau also regularly uses French, especially during their concerts, in order to make everybody understand what the songs are about. Nadau's singer Michel Maffrand views their bilingual performances as »nostalgia and collective memory«, not only »place« as Weston argues. It means that most of Nadau's work deals with an ideal representation of Occitan's past culture. Although Nadau is not the only band that shifts languages in order to compromise between their identity and what the audience can understand, they are probably the band that tapped into it the most as interactive storytelling engaged with nostalgia:

»I use French during the show in order to introduce the songs in Occitan, so the audience know what it is going to be about. But it's not a simple translation, I do it in a comic way, with jokes and stories. Actually, every presentation is part of the show, it's a piece of art in itself« (ibid.). 
In the same way that they mix French and Occitan, they also use many instruments that are considered traditionally Occitan to accompany the guitar, the bass and the drums. But if Nadau can be considered a popular music band and not a folk one, it is due to the fact that they compose their own melodies and lyrics, even if they are highly inspired by traditional folk music. Indeed, they find the lack of compositions in Occitan regrettable and think that »bands playing dance folk music are a little bit stuck in their own thing « (ibid.). Nadau doesn't play at folk festivals. Moreover, Nadau's songs are registered at the SACEM (the French professional association that collects and redistributes artists' rights), while the folk repertoire belongs to everybody. Yet in concrete musical terms, the difference can be vague. In the case of Nadau, when I asked the singer how he distinguishes between folk melodies and his creations (that are, from my point of view, quite close), he hesitated and finally argued that he »naturally inherited " them from the traditional Occitan culture and sounds. Other Occitan artists are against the notion of copyright. This is particularly the case for Artús (2000-present, formerly known as Familha Artús), an experimental band that takes great inspiration from the Occitan repertoire and uses traditional instruments, but in an unorthodox way (with heavy distortion for instance). Artús' hurdy-gurdy player Romain Baudoin argues that the oral tradition is opposed to the notion of copyright in the sense that "you can't say sthat song belongs to me, if you want to play it you have to pay me<, because what is really yours? What did you invent? « (Romain Baudoin 2014). This difference between Artús and Nadau regarding copyright hints at a generational gap between Nadau and the rest of the Occitan popular music scene:

»There's almost no pure musical creation in Occitan, almost nobody sings Occitan in a modern way. It's a shame. I feel that the continuation of what we did is more than uncertain. I tried to train some younger people, but then they have to touch the audience. There's a contradiction today in the fact that young people play popular music, but they're not popular [...]. It remains underground [...]. To tell the truth, I'm not very enthusiastic « (Michel Maffrand 2014).

Indeed, while younger bands like Artús or Massilia Sound System (1984-present) worked hard to create networks of Occitan bands through their own labels (respectively Pagans Records and Roker Promocion), Nadau does not sponsor anyone, despite their great fame. Nadau's singer does not actually believe in music sponsorship and thinks Nadau's audience is specific in the sense that they seek a »lost memory « of their disappearing culture (not to say disappeared). Thus, among the Occitan world, if the language is obviously a central part of the music's identity, it is definitely not the only cri- 
terion of authenticity. Since Nadau is an exception in terms of popularity and longevity, it is notable that other Occitan popular bands that don't focus on nostalgia have faced several obstacles in their career and in the recognition of their Occitan identity. Nadau's effort on nostalgia is in fact often criticized by these other bands such as Papa Gahus for reducing Occitan identity to a performance of an idealized rural society:

»Nadau is like a dinosaur. They oblige other Occitan bands to live in their shadow [...]. People go see them live to hear stories from an era that doesn't exist anymore and won't exist again [...]. Nadau makes money out of that [...]. It's creepy when bands embody a culture or an identity and think they are a messiah« (Sylvain Carrère 2014).

If the link between nostalgia and music, in the sense of Nadau, can constitute »a technology for spinning the apparently continuous tale of who one is « (DeNora 2000: 63), other bands then seem sceptical about its capacity to generate modern and politically active identities, especially since nostalgia is considered as »the consciousness of a malaise in the present «, and as »the selective and imaginary mental reconstruction in the present in order to alleviate this unease« (Lebrun 2009: 42).

Paradoxically, while $\gg$ the increasing dominance of the retro market in contemporary popular culture is enabling respective post-war generations [...] to engage in nostalgic representations of what it means to be young « (Benett 2001: 153), the case of contemporary Occitan music does not show a significant impact on the youth. Because of the competition with global pop music, Occitan popular bands are often little known or ignored by young people living in the south of France, which is regrettable knowing the important role of music in teenagers' lifestyle (Octobre/Mercklé/Détrez/ Berthomier 2010). Even the Occitan artists I interviewed acknowledged having been more into English or American rock, punk or rap before finding some interest in Occitan culture and traditional folk music (but their commitment to the folk scene remains ambiguous, as I will argue below).

In the end, what can be said is that by trying to »save identity and culture, the folk movement failed to truly connect with young people, and that an ambassador of Occitan popular music such as Nadau has had to rely heavily on nostalgia in order to gather a broader audience.

However, during the 1990s and 2000s, Massilia Sound System's reggae/ ragamuffin in French and Occitan succeeded to show the youth a positive and open image of Occitan culture (Chabaud 2005). Unlike the bands from Nadau's activist generation, Massilia Sound System was more perceived as a reggae/dub band than »just« an Occitan band, even if their first record was 
named Parla Patois (»speak dialect « in Occitan). As an acclaimed reggae/ dub band, they quickly turned professional and drew attention to other Occitan bands (»the Mediterranean music buzz«, see Suzanne 2010: 159): Fabulous Trobadors (1987-present), Nux Vomica (1992-present), Gacha Empega (1996-1999), Dupain (2000-present), Lo Cor de la Plana (2003present), etc. However, the period when this Occitan scene (especially Dupain, Fabulous Trobadours and Massilia Sound System) could benefit from marketing support by major record companies is now over. Most of the Occitan artists remaining from the 1990s (Moussu T and Forabandit's singer Sam Karpienia) and the new ones (Artús, Papa Gahus, Faune, Mauresca and Doctors de Trobar for instance) only get contracts with indie labels or have to create their own labels, driving the Occitan scene further underground.

\section{Authenticity at Heart: The Occitan Language as a Cultural and Creative Tool}

Songs in Occitan necessarily confuse the francophone listener. The words can be close to French (many of them share the same root, »parlar « is »parler«, »manjar « is »manger«, etc.), yet the whole language sounds strange, almost exotic (sometimes similar to Spanish, with verbs like »cantar «, »costar« or »saber « for instance). Today, its »natural« use within the public sphere is quite rare (Bernissan 2013), even in cafés or other social spaces. In this sense, it can be considered as a »post-vernacular « language (Shandler 2006: 19), which means that its use needs to be justified and that the meaning is more to be found in the use itself and the context than in the content. For being so rare, Occitan has been almost sanctified by a part of the population that cannot speak it but still feel a symbolic attachment to it, but also by activists and legitimate »new speakers« (Costa 2015: 129133).

One of the main reasons why popular artists use Occitan, beyond their obvious cultural attachment, is the »aesthetic « value for singing. Unlike »new speakers « who attempt to homogenize the Occitan language, my interviewees prefer local variants of Occitan, considering that they fit some music genres better than others: rock is supposed to work well with the Gascon variant, rap and reggae with Provençal for instance: »In Gascon it's easier to play rock, or even more radical than rock. Try to sing reggae in Gascon, it's gonna sound as joyful as a burial, I promise. It's like Basque, it has a lot of scratchy sounds« (Sylvain Carrère 2014). 
The local scenes follow this geographic and linguistic separation. In Provence, especially in Marseille (where Provençal is spoken), there is a vibrant hip-hop and reggae scene, while in western Occitania (where Gascon is spoken), the scene is more dominated by punk and rock bands. This also reflects the difference between urban and rural areas, where lyrics and themes are almost opposed. On the rural side (Gascony and Auvergne), bands have a tendency to use dark (Hitilh, 2009-present), pagan (Artús) or even satanic lyrics (Stille Volk, 1994-present) that are close to a certain traditional troubadour corpus. The urban side is more focused on social and realist issues such as labor life (Sam Karpienia), neighbourhood life (Mauresca), otherness and identity (Massilia Sound System). Beyond their aesthetic value, Occitan variants are cultural tools that merge with different artistic purposes.

Despite this diversity among the Occitan popular music scene, there is a common ideology of openness towards other musical and cultural traditions, often inspired by Occitan writer Felix Castan. Musical genres from metal to punk, from rap to reggae, all blend more or less harmoniously with Occitan. At a more political level, none of these bands are separatists. But behind the simple use of Occitan the bands express a political demand for the recognition of the specificity of their culture by French institutions and media. They feel they belong to France but also think that French culture could benefit from Occitan culture:

»I believe in what Occitan literature and music could bring to French culture, so it could be more plural, whereas foreign languages won't be of any help. Occitan comes from the inside and it left a very strong mark in France. It's very important to know what you're marked by, but also to find other artistic centres than Paris [...]. This is why I'm an Occitanist and I will keep doing things in Occitan« (Claude Sicre 2014).

If the words to qualify Occitan's marginalization can be inordinate (Sylvain from Papa Gahus said »genocide ), there is an overall rejection of any kind of victimized position. In fact, they despise the discourse that blames the French state for the disappearance of Occitan. Occitan popular artists have a specific commitment to their music (more »do it yourself « and more independent than folk music) that makes them very suspicious towards activists playing the victim card and waiting for compensation (in the form of subsidies), with no real artistic commitment. Many artists deplored what I call »regionalist opportunism « that consists of Occitan bands finding shows only because they sing in Occitan, even if they are amateurs. Thus, the simple use of the Occitan language in any type of music is not considered enough 
to represent Occitan identity. The notion of »artistic commitment « and, more generally, the reflexive way of building an artistic identity that considers the audience's reception are far more valuable than the language in itself:

"It's not because you sing in Occitan that we're all going to be friends [...]. Maybe you don't like my music, it's subjective. But you can't say that we didn't work hard on it [...]. That's what I don't like about a lot of Occitan music, it's just a pretext, they don't know anything about what they play, there is no commitment. [...] There is this band Lou Dalfin that is supposed to be >Occitan rock < but it's just shitty commercial pop music from the 1980s. If they were singing in French, nobody would listen to them « (Romain Baudoin 2014).

"With Massilia we always worked from a basis of >technical specifications [>cahier des charges‘]: how to make a song that is going to be interesting, how to bring across a message, what we shouldn't say [...]. It was crafted and was not just a matter of pure inspiration [...]. Basically the idea was to position yourself towards society and your environment, so the audience can easily make the song theirs. You have to be careful with the language for instance, it's not just about Occitan but also about the popular language around you, so the greatest number of people can understand you « (Tatou 2014).

Many bands I interviewed use the Occitan traditional repertoire at some point ${ }^{3}$, but they also feel the need to compose, to move forward, not to be stuck in the past, not to be a prisoner of their own regional identity. Their art is a fight against both the disappearance of their cultural specificity and the opposition to any cultural change. Fabulous Trobadors' career (1987present) illustrates this »identity struggle«. When they started, they were seeking a rural spirit in Occitan culture close to American blues; a kind of wildness that they could not find in French mainstream music. Occitan music was supposed to be »rural« and »basic« (roots), however, Fabulous Trobadors quickly gave up with Occitan folk music when they realized that most of the songs were »too soft « and »pop«, as if »their original essence had been misunderstood « by revival activists (Claude Sicre 2014). To compensate for this lack of authenticity, they started to look for another musical form that could fit the sound of the Occitan language without betraying its rural identity. Surprisingly, Fabulous Trobadors' singer Claude Sicre found it in north-eastern Brazilian percussion techniques:

3 Among the bands I interviewed, Artús, Hitilh, Stille Volk, Nadau, Faune and Baal are those using Occitan instruments and lyrics the most. 
»[What we play] is a basic tambourine-based music as powerful as any rap or reggae. It is linked to our civilization; we can play in the street, in the subway, in the bus, anywhere. For me, the voice, the tambourine, it all goes deep into our history, until the Antiquity. It's not just about modern cities. You can stop, play again, it's spontaneous. You can do that with machines too, but it's more complicated. [...] Our message is that you can assume whatever you do and take yourself out of where you are. It's very positive, you can do anything from the bottom, you can change the world, there's no need to be afraid of anybody, of anything « (ibid.).

Despite his fame as an Occitan artist, Fabulous Trobadors' singer Claude Sicre finally gave priority to the French language in his songs in order to address his message to a larger and younger audience: »[The young people,] they liked our music [in Occitan], but I wanted to tell them things they could really understand « (ibid.). For him, the message was more important than the language, especially because he found a musical language to match his message. His music was authentic enough and did not need the Occitan language to prove anything, because the Occitan identity, in his mind, was not very different from what inspired him really (American blues and northeastern Brazilian music). In Fabulous Trobadors' music, »Occitanness« according to the folk representation then became very relative. The main sounding proof of folk Occitan identity was eventually the accent, but especially the typical singing format (»battle $«$ ) of the troubadour culture that had originated in Occitania.

Other artists, such as Sam Karpienia (Dupain and Forabandit's singer) or Tatou (Massilia Sound System, Moussu T e lei jovents), now try to negotiate their Occitan identity while singing in French, especially by keeping their Occitan accent and themes related to the Occitan world (Moussu T et lei jovents sing a lot about the place they live in for instance, see Mademoiselle Marseille or Inventé à la Ciotat). Occitan artists generally shift from Occitan to French with no orthodoxy, which is one of their trademarks. Moreover, many of them also try to »Occitanize « their modern music beyond the single use of the language. Goulamas'k (ska/punk), Hitilh (metal), and Papa Gahus (rock) all occasionally use folk instruments (such as the hurdy-gurdy or the cabrette). 


\section{Shaking the Habitual in Occitania, an Ongoing Struggle}

Even in Occitania, this popular music can be confusing for the audience, and not only because Occitan is less and less spoken. Many musicians argued that during concerts the comprehension of the lyrics is pretty low, which means the language in itself shouldn't be the problem for Occitan music's lack of recognition. The »problem « of language is in fact highly ideological, despite the fact that Occitan popular music singers claim to use Occitan for its aesthetic values.

Occitan activists have accused bands that alternate between singing Occitan and French of giving up the Occitan language. Indeed, for many activists the language remains an important symbol of the Occitan identity. Mauresca's members initially did not want to »think too much « about the language, because they sang in French or Occitan »as it came« (»au feeling «, Chab 2014). Even though they claimed to defend Occitan culture, it was not a sufficient response to these accusations. It created tension among the band, a cognitive dissonance that they finally resolved by starting with Yellow a side project called Doctors de Trobar, a 100\% Occitan rap band.

»The closest to protest rap we did with Mauresca was always in French. Some people thought it was cool to understand it all [in the case of the song >Stéréotype <], the message was clear and was about Occitan. If we had done it in Occitan... [it would have had less impact]. Then people say: 'you play rap but you do it in French, nobody wants to make Occitan rap, everything you protest against is in French<, so then we started Doctors de Trobar [...]. It was more of a challenge, while `Stéréotype « was about being understood « (Chab 2014).

This new band is what I call a »necessary niche«: a musical proposition that resolves the ideological tensions of the scene, even if the audience is very small. Nevertheless, as any musical niche, it can go further and experiment more than mainstream music. In Doctors de Trobar's case, the experimentation is to be found in the lyrics inspired by American thug life mythology, transposed into Occitan:

"You do some graffiti, you smoke some weed, you chase some girls, that's what it's about [...]. We don't give a shit about politics [...], what we do is political because we gather the people, the idea is to spend a good time together [...]. At a show in Montpellier, I was playing that ego trip song with a part about the big dick I have [...] and after that a guy came to tell me that it was the best line ever« (Yellow 2013). 
By twisting Occitan traditional themes, Doctors de Trobar also deconsecrates the language and the essentialist tendency to think that Occitan should only be used to address certain topics.

Many musicians I interviewed confessed that the folk scene's audience (»les tradeux «) rejected them at some point because of their unorthodox use of the language, as in Doctors de Trobar's »extreme case (see below), but also in the way other bands such as Stille Volk use traditional instruments, texts and melodies:

»For this album [Satyre Cornu], we had Occitan lyrics from the traditional repertoire and we added some verses of our own. We are generally very criticized [by the folk audience] for taking such freedom, even if it's what Occitan people have been doing forever. Why would you have 30 versions of the same song in the traditional repertoire then? [...] It really drives us mad that these people [from the folk audience] claim to be >folk < or spopular , when they actually turn it into something orthodox [>une doxa<]. I used to play on traditional Occitan dancing parties (>baloche $<$ ), but it's over now. I used to like playing folk music with an acoustic guitar but people couldn't stop saying I couldn't do that because the guitar was not a traditional instrument [...]. It's so absurd « (Florant Mercadiers 2014).

In the purist folk scene, new instruments (electrified or not) are often despised, as if it was treason to the traditional Occitan identity. Artús is a good example of this disparity in the sense that some members started as metal and rock musicians, but then quickly became professional folk instrumentalists experimenting on the traditional repertoire. The album Drac (2010) is representative of their noisy experiments on traditional Occitan melodies and lyrics, with heavy drums and bass, distorted hurdy-gurdy and screeching vocals. Their music always originates in a traditional song they decide to »twist « until the point »it is no longer recognizable« (Romain Baudoin 2014). The repertoire was helpful at the beginning because they were not fluent enough to write meaningful lyrics in Occitan, even if some of the few lines they added to traditional songs were sometimes - ironically - reappropriated by folk bands. In general, Artús' members aspire to compose all their music, but their work on Occitan repertoire was a way to deeply connect with their culture. In the end, this process makes Artús more an avant-garde type of band, in spite of their own self-concept:

»In some way, we could be considered as real traditional Occitan musicians, because we inherited it from our parents. But in reality, to be a real traditional musician, people from here have to identify you as part of the local culture, there has to be a social bond. And with Artús it's not the case. Most of the people don't understand what we do and they don't care [...]. It's only when 
we played traditional dancing music that people identified with our music« (ibid.).

During a traditional Occitan dancing party (»bal folk«), the songs are codified in order to allow everybody to dance to the same patterns. This dance music which was collected and recomposed long ago is more »popular «, in the sense that it is shared and appreciated by a larger Occitan audience, especially older people. As a result, the inclusion of non-folk bands in folk events can be perceived as a choice based on the pretext of attracting a younger audience. Indeed, folk scene members sometimes invite Occitan popular bands to perform on stage, in an attempt to attract a new audience, but at the risk of appearing artificial and failing completely:

»When you rap in Occitan, people think you're gonna wear clogs [...]. One day there was a big Occitan event called Total Festum and the organizers invited us to play [...]. It was quite well paid [...] but when we arrived we realized that we were gonna play in front of old retired people and folk dancers having lunch [...]. We started to play but we were so pissed off $[\ldots]$ and then a guy came and asked if we could change the music [...]. So my first reaction was: >go fuck yourself^, but then I realized the guy was actually right! He didn't sign for that, he expected a bunch of assholes playing accordion so he could dance bourrée [a traditional Occitan dance]« (Yellow 2013).

Despite this contentious relationship with the traditional Occitan audience, many artists I interviewed (especially those using the folk repertoire) acknowledged that they play in folk bands on occasion, but they are very selective about whom they play with (Artús is close to the bands from the label La Novia for instance). Even if many despise the folk scene's narrowminded mentality, they listen to traditional Occitan music and go to folk events from time to time. For many, it is part of their rich and complex musical heritage. More than a simple attachment or taste, traditional music can also be a way to make a living for some of these musicians (Artús, Hitilh, Baal and Faune), through teaching music or as professional musicians. And if they cannot earn a living from the music itself, they do through the teaching of Occitan (Florant Mercadiers from Stille Volk) or working for Occitan media (Yellow from Doctors de Trobar) or institutions (Sylvain Carrère from Papa Gahus).

Professional and artistic relationships are not only complicated within the Occitan folk scene, but also with the local non-Occitan popular music scene. Venues and festivals usually do not care much about music in Occitan (either folk or modern), except when they want to appear Occitan-friendly in order to receive subsidies. For example, the band Artús received a propo- 
sition to play at Garorock, an important festival in the south of France that draws around 50,000 people. They then heard that the festival needed an Occitan band to get a subsidy from the regional council and that they would play on a special stage, as if they were not part of the real line-up. They finally refused to go, arguing that they needed to be recognized for the entirety of their music, not just the Occitan part (Romain Baudoin 2014). All the bands I interviewed put emphasis on how difficult it was to book shows (except Nadau), even with national media support. ${ }^{4}$ In fact, composing in Occitan often means giving up a large amount of exposure: »nobody cares about you as long as you sing in Occitan« (Claude Sicre 2014).

Yet, one band, Lo Cor de la Plana, found a way out of this paradoxical situation thanks to the »world music « field, which is not a musically satisfying category, but at least has a viable international market. The »world music « market usually relies on an exploitation of exoticism that does not work so well on a national scale, especially in France, where local folk influenced music is often perceived as backward looking or unfashionable. However, the »world music « scene provides »new global spaces that allow musical exchange and, in spite of certain inequalities, greater circulation of people, technologies and ideas « (Stokes 2014: 42) where local and rare identities are enhanced and highlighted. For being independent, Lo Cor de la Plana is a good example of the sglobalization from below« (ibid.: 35). Without marketing support by major companies, Lo Cor de la Plana managed to tour around the world (New York Global Fest, Fes Festival of World Sacred Music in Morocco, Konya Mystic Music Festival in Turkey, Yokohama National University in Japan, Solin World Music Festival in Croatia, etc.) and even received positive articles from foreign media (New York Times, December 15, 2008; December 14, 2012). As an Occitan polyphonic vocal band with traditional percussions, the question of why their music fits international »world music « standards better than other Occitan bands remains open.

In conclusion, if the language specificity of Occitan bands makes their career management complicated in France, the cultural value of these bands among French and international music markets is significant. Indeed, their music goes beyond a simple use of an exotic rural language and in-

4 Fabulous Trobadors in Télérama (June 30, 2007), Le Monde (June 9, 1995; November 6, 1998; March 26, 2010), Le Figaro (September 30, 2003), Libération (June 19, 1995; October 2, 2003), Le Parisien (October 11, 2003), Les Echos (November 16, 2007); Massilia Sound System in L'Humanité (November 22, 2002), Le Monde (October 12, 2000; October 27, 2007; October 21, 2014); Mauresca in L'Express (April 1, 2015), France Inter (October 5, 2011); Artús in Le Monde (August 18, 2008), etc. 
tends to build new alternative identities. This dynamic is certainly not a widespread movement in Occitania, but it seems to have sustainably settled, and it is probably its relative remoteness or undergroundness that makes it such a diverse, freethinking and experimental scene.

\section{Bibliography}

Bennett, Andy (2005). Cultures of Popular Music. Maidenhead, etc.: Open University Press.

Bernissan, Fabrice (2013). »Discours volontaristes et effets réels. La situation de l'occitan.«In: Lengas. Revue de Sociolinguistique 73; http://lengas.revues.org/ 95 (accessed March 30, 2015).

Candau, Joël (1998). Mémoire et identité. Paris: Presses Universitaires de France.

Cestor, Elisabeth (2005a). Les musiques particularistes: chanter la langue d'oc en Provence à la fin du XXe siècle. Paris: L'Harmattan.

Cestor, Elisabeth (2005b). »Minorités actives dans le milieu musical régional.« In: Volume! 4:2, pp. 51-60.

Chabaud, Sylvain (2013). "Le chant en occitan, une expérience récente et originale de prise en main d'une culture et d'une langue. «In: Lengas. Revue de Sociolinguistique 74, http:/ /lengas.revues.org/375 (accessed April 25, 2015).

Charles-Dominique, Luc (2011). "Les emblèmes instrumentaux régionaux du revival français. «In: Langue, musique, identité: Actes du colloque tenu à Poitiers, 21 23 novembre 2007. Ed. by Jeremy Price, Licia Bagini and Marlène Belly. Paris: Publibook, pp. 137-179.

Charles-Dominique, Luc / Defrance, Yves (2008). »Réhabiliter, repenser, développer l'ethnomusicologie de la France.« In: L'ethnomusicologie de la France: De l' »ancienne civilisation paysanne « à la globalisation: Actes du colloque "L'ethnomusicologie de la France «, 15-18 novembre 2006. Ed. by Luc Charles-Dominique and Yves Defrance. Paris: L'Harmattan, pp. 11-23.

Costa, James (2015). »New Speakers, New Language: On Being a Legitimate Speaker of a Minority Language in Provence. «In: International Journal of the Sociology of Language 231, pp. 127-145.

DeNora, Tia (2010). Music in Everyday Life. Cambridge, etc.: Cambridge University Pres.

Donnat, Olivier (ed.) (2003). Regards croisés sur les pratiques culturelles, Questions de culture. Paris: Documentation française.

Giordan, Henri (2002). »Le pouvoir et la pluralité culturelle.«In: Hérodote 105, pp. 178-190.

Hennion, Antoine (2011). »Présences du passé: Le renouveau des musiques 'anciennes'.« In: Temporalités 14; http://temporalites.revues.org/1836 (accessed July 24, 2015).

Lebrun, Barbara (2009). Protest Music in France Production, Identity and Audiences. Farnham, Burlington, VT: Ashgate.

Nelli, René (1989). "Le roman de Flamenca «: un art d'aimer occitanien du XIIle siècle. Institut d'estudis occitans; Centre internacional de documentacion occitana; Centre national d'études cathares René Nelli, Toulouse, Béziers: Villegly. 
Octobre, Sylvie / Détrez, Christine / Mercklé, Pierre / Berthomier, Nathalie (2010). L'enfance des loisirs. Trajectoires communes et parcours individuels de la fin de l'enfance à la grande adolescence. Paris: Ministère de la culture et de la communication, Département des études, de la prospective et des statistiques.

Shandler, Jeffrey (2006). Adventures in Yiddishland: Postvernacular Language and Culture. Berkeley, CA: University of California Press.

Stokes, Martin (2014). »Créativité, globalisation et musique.«In: Volume! 10:2, pp. 29-45.

Suzanne, Gilles (2010). »Effervescences musicales en Méditerranée. «In: La pensée de midi 10:31, pp. 159-165.

Tenaille, Frank (2008). Musiques et chants en Occitanie création et tradition en pays d'oc. Paris: Le Chantier.

Weston, Donna (2012). »Béarn Folk Rock: Language, Place and the Soundscape of the New Europe. «In: Journal of Intercultural Studies 33:2, pp. 157-174.

\section{Interviews}

Aurélien (Enloc), October 2013.

Chab (Mauresca), January 2014.

Claude Sicre, March 2014.

David (Gojats of Hedas), December 2013.

David and Jordan (Hitilh), January 2014.

Florant Mercadiers (Stille Volk), May 2014.

Fred (Goulamas'k), January 2014.

Hakim (Cri'art), October 2013.

Jacques Puech (Faune), December 2013.

Laurent Moulédous (Hart Brut), October 2013.

Lou Davi, March 2014.

Michel Maffrand (Nadau), March 2014.

Roman Baudoin (Artús), February 2014.

Sam Karpienia (Forabandit), February 2014.

Simon (Baal), November 2013.

Sylvain Carrère (Papa Gahus), May 2014.

Tatou (Moussu T e lei Jovents / Massilia Sound System), January 2014.

Yellow (Doctors de Trobar), December 2013.

\section{Discography}

Familha Artús (2010). Drac. Pagans FZM036.

Moussu T e lei Jovents (2005). Mademoiselle Marseille. Manivette Records MR 01. Moussu T e lei Jovents (2007). Inventé à la Ciotat. Manivette Records 2741549. Stille Volk (2001). Satyre Cornu. Holy Records HOLY66.6CD. 


\begin{abstract}
This article observes how popular music groups singing in Occitan (a regional language) can continue to exist and create music in southern France. Choosing to sing in Occitan or/and to use traditional instruments in an unorthodox way, as these groups do, reveals complicated relationships with the Occitan traditional folk scene. Nevertheless, even though the influences of new Occitan bands can be traced to global music genres (rap, rock, etc.), they also tend to find a compromise with the local identity that has been defined by Occitan activists. Thus they modestly - yet actively - participate in a global movement of new regional identities.
\end{abstract}




\section{GfPM}

\section{Gesellschaft für Popularmusikforschung / German Society for Popular Musik Studies e.V.}

\section{(vormals Arbeitskreis Studium Populärer Musik e.V.)}

Die GfPM ist der mitgliederstärkste Verband der Popularmusikforschung in Deutschland.

Die GfPM fördert fachspezifische und interdisziplinäre Forschungsvorhaben in allen Bereichen populärer Musik (Jazz, Rock, Pop, Neue Volksmusik etc.).

Die GfPM sieht seine Aufgaben insbesondere darin

- Tagungen und Symposien zu organisieren,

- Nachwuchs in der Popularmusikforschung zu fördern,

- Informationen auszutauschen,

- wissenschaftliche Untersuchungen anzuregen und durchzuführen.

Die GfPM ist ein gemeinnütziger Verein und arbeitet international mit anderen wissenschaftlichen und kulturellen Verbänden und Institutionen zusammen.

Die GfPM gibt die Zeitschriften Beiträge zur Popularmusikforschung und Samples. Notizen, Projekte und Kurzbeiträge zur Popularmusikforschung (www.gfpm-samples.de) sowie die Schriftenreihe texte zur populären musik heraus.

Informationen zum Verband und zur Mitgliedschaft:

Gesellschaft für Popularmusikforschung (GfPM)

Ahornweg 154

25469 Halstenbek

E-Mail: barber@popularmusikforschung.de

Online: www.popularmusikfoschung.de 